\title{
Porroca: An Emerging Disease of Coconut in Central America
}

\author{
Gregory S. Gilbert, Department of Environmental Studies, University of California, Santa Cruz, 95064; and \\ Ingrid M. Parker, Department of Ecology and Evolutionary Biology, University of California, Santa Cruz, 95064
}

\begin{abstract}
Gilbert, G. S., and Parker, I. M. 2008. Porroca: An emerging disease of coconut in Central America. Plant Dis. 92:826-830.

Porroca is a lethal disease of coconut (Cocos nucifera) emerging in Central America. Previously known only from Colombia, it has spread rapidly across the Isthmus of Panama in the last decade. Porroca is characterized by the production of stiff, dwarfed leaves, usually followed by the death of the palms within 2 years. We describe the long-distance spread of the disease as determined from regular censuses of more than 200,000 coconut palms in the indigenous Comarca of Kuna Yala and the Republic of Panama. Spread is temporally and spatially variable, with the disease moving across the landscape as much as $40 \mathrm{~km}$ per year. Porroca may represent a significant new threat to coconut production in the Caribbean Region.
\end{abstract}

Additional keywords: emergent plant disease, little leaf, palm, phytoplasma, San Blas

Porroca is a lethal disease of coconut (Cocos nucifera L.) currently described as only found in Colombia and Panama where it has caused localized losses of thousands of coconut palms over the last several decades $(3-5,8)$. Beginning in the 1980s, it spread quickly westward along the Isthmus of Panama. Because of the severity of the disease and the observed recent expansion of its range, porroca is of potential concern for coconut production throughout the tropical and subtropical Americas. Here we provide a detailed description of the symptoms, development, and patterns of spread of porroca in $\mathrm{Pa}$ nama over the last decade.

Several names have been proposed for this disease, including porroca (which supposedly derives from an indigenous word in Colombia) (5), hoja pequeña (little leaf) (9), and coconut apical necrosis (3). The last of these names is clearly inappropriate since necrosis is a minor and variable component of the symptoms associated with the disease. We adopt the name porroca of coconut because of the historical precedent and its widespread use.

Corresponding author: G. S. Gilbert

E-mail: ggilbert@ucsc.edu

* The $\boldsymbol{e}$-Xtra logo stands for "electronic extra" and indicates that Figure 2 appears in color in the online edition.

Accepted for publication 15 January 2008.

doi:10.1094/PDIS-92-5-0826

(C) 2008 The American Phytopathological Society
The literature on porroca is quite limited and not widely available. The first report of this disease was made by Ferrand in a 1960 FAO report on oil-producing palms in Colombia (5). Ferrand noted that porroca was the cause of death of thousands of coconut palms annually in northwestern

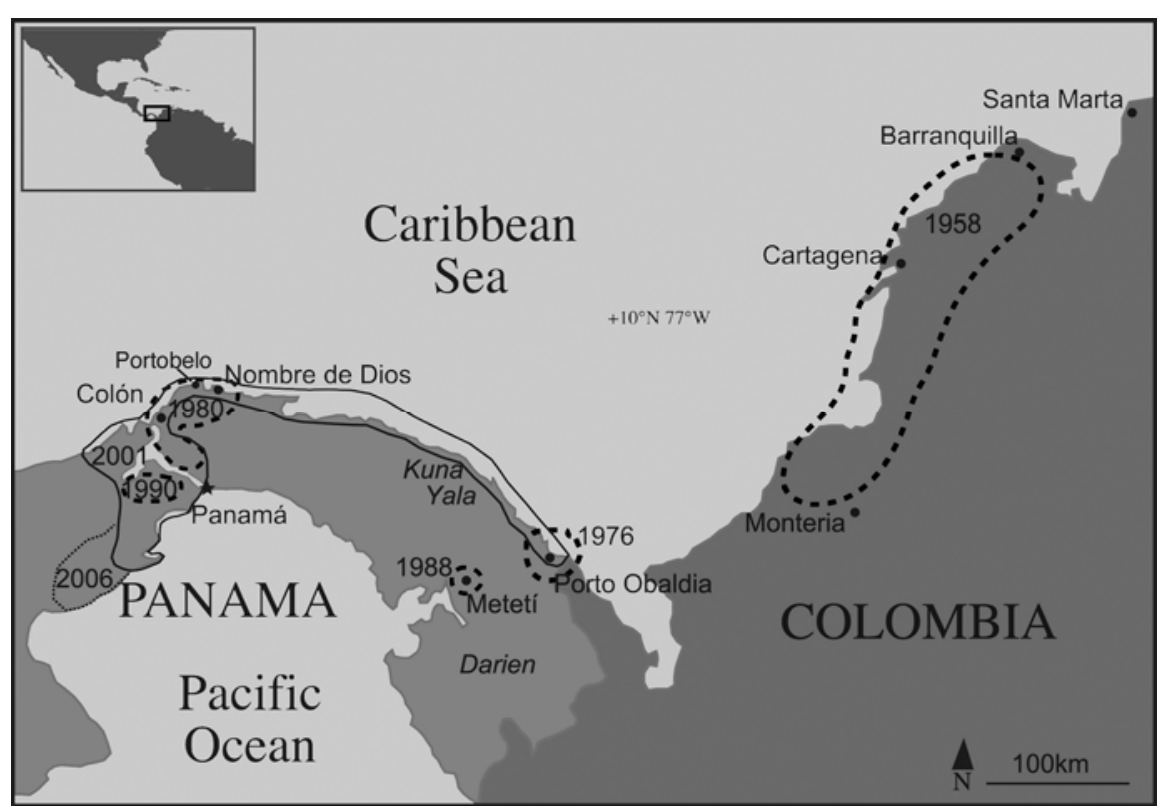

Fig. 1. Historical records of porroca disease of coconut (dashed lines) and observed distribution in Panama in 2001 (solid line) and 2006 (dotted line) in this study. First reports indicated that porroca was restricted to a portion of the Caribbean slope of Colombia (5). In 1976, it first appeared across the Panamanian border (8) and subsequently spread to the Colón and Panama provinces in the 1980s and 1990s (3,4). Palms with porroca-like symptoms were reported from a site in Darién Province, near Metetí in $1988(3,4,8)$. The 2001 survey found porroca along the Caribbean Coast and on offshore islands from the Colombian border to the end of road access west of Colón and throughout the Colón and Panama provinces in central Panama. By 2006, it had spread along the Pacific slope. Extensive searches showed no symptomatic palms within $100 \mathrm{~km}$ further west than the indicated areas. Darien province was not surveyed. 
Santa Isabel (8). Esquivel reported symptomatic palms in the province of Panama by 1980 and west of the Panama Canal by $1990(3,4)$ (Fig. 1). To the east of Colombia, coconut palms with porroca symptoms became more common in French Guiana and northeastern Ecuador beginning in the early 1990s (Bernard Perthuis, CIRAD, personal communication).

During the 1990s, porroca became noticeably more common in the province of Panama, causing widespread concern about the effects of this disease on coconut production on the isthmus. An epidemic of porroca was of particular concern on the Caribbean Coast where coconut production is economically and culturally vital to the indigenous Kuna people of the Comarca of Kuna Yala and the Afro-Antillean Costeño people in regions east and west of the city of Colón. The Kuna rely heavily on coconut as a staple food, a primary source of cash income, and a cultural icon $(10,11)$. The local impacts of porroca can be severe; in one plantation in Colón Province, coconut production was reduced from 12,000 nuts to fewer than 2,000 nuts per month within 5 years from the first appearance of porroca (8).

In palms affected by porroca, the apical meristem, internal parts of the trunk, and the roots of symptomatic palms appear normal and there is no macroscopic or microscopic evidence of fungi, bacteria, nematodes, or other damage (5). No pathogen causing porroca has been found. In the absence of the identification of a disease agent, various authors have suggested that viruses, soil nutrients, moisture conditions, insect attack, and interactions of these factors should be further investigated $(5,9)$. However, Muñoz suggested that porroca does not appear to be associated with particular soil moisture or nutrient conditions in Panama and that treatment with insecticides, fungicides, nematicides, and antibiotics had no effect on porroca symptoms (8). In a brief description of porroca in an account of the principal diseases of coconut in Caribbean Colombia, Ramirez Naranjo was the first to note that affected palms sometimes recover (9).

Since previous studies presented only brief descriptions of the disease, we provide here the first detailed description of the symptoms, development, and patterns of spread of porroca of coconut.

\section{MATERIALS AND METHODS}

Description of symptom development. To provide a detailed description of the symptoms and development of porroca, symptomatic coconut palms (Cocos nucifera L., Atlantic Tall ecotype) were felled, dissected, and studied in detail. Studies were done in two locations in the Republic of Panama; in 1999 at the research plantations of the Ministerio de Desarrollo Agropecuario (MIDA) of $\mathrm{Pa}-$ nama $\left(9.57194^{\circ} \mathrm{N}, \quad 79.48639^{\circ} \mathrm{W}\right)$, near
Nombre de Dios, Colón Province, and in 2001, at Didistuku $\left(9.00694^{\circ} \mathrm{N}\right.$, $\left.77.78861^{\circ} \mathrm{W}\right)$, a mainland cooperative plantation of the Kuna people of Dubpak (Isla Pino) (Comarca of Kuna Yala = San Blas Province). Additional healthy palms were studied at Dubpak $\left(9.00861^{\circ} \mathrm{N}\right.$, $77.75972^{\circ} \mathrm{W}$ ) in 2001.

Disease distribution and spread in Panama. We documented the recent geographic expansion of the incidence of porroca disease across Panama by recording the status and location of nearly 200,000 coconut palms in eastern and central $\mathrm{Pa}$ nama in repeated surveys between 1998 and 2006. Reconnaissance in 1997 indicated that porroca was not present in western Panama. Between 1998 and 2001, we conducted surveys along the Caribbean Coast of central and eastern Panama as well as road-based surveys in central $\mathrm{Pa}$ nama. By 2000, porroca was found throughout the coastal region, so from 2001 to 2006 , we focused our attention primarily on expansion westward in inland areas and along the Pacific slope of central Panama. We used a Trimble Pro-XRS GPS unit (Trimble Navigation Ltd., Sunnyvale, CA) to map the linear position of all healthy and symptomatic palms either by boat (coastal surveys) or car (road surveys).

Coastal surveys. In annual surveys from 1998 to 2001 (June to August), with the help of Edgardo Soo and Victor Manuel Avila from the Kuna General Congress, we mapped the distribution of porroca in central and eastern Panama. There is no road access in Kuna Yala, so the Kuna Yala surveys were conducted by boat along the Caribbean Coast from Nombre de Dios (Colón Province) eastward through the Comarca of Kuna Yala to the Colombian border. Surveys encompassed $392 \mathrm{~km}$ of coastline and all 306 islands in the San Blas Archipelago that had coconut palms. For most of this region, the mountainous terrain abuts the coastline, so most coconut palms are restricted to a narrow band near the coast. We did not survey palms in inland plantations along rivers, which represent only a small fraction of coconuts in the region because Kuna grow few coconuts away from the coastline (6). Islands were small enough to see all palms clearly from a boat just offshore. We usually observed the palms with binoculars from a distance of 20 to $100 \mathrm{~m}$, which provided an optimal viewing angle to see the young leaves where porroca symptoms first develop. Within the Comarca, we mapped more than 167,000 coconut palms $(103,000$ on the mainland and 64,000 on islands). Of $392 \mathrm{~km}$ of coastline, less than $14 \mathrm{~km}$ did not have a significant density of coconut palms (defined as $>2$ palms per kilometer) and there were no coastal stretches longer than a few hundred meters nor any islands without coconuts. Approximately 30,000 additional palms were mapped along $92 \mathrm{~km}$ of coast between Nombre de Dios and the western border of Kuna Yala.

Road surveys. To census palms in central Panama (i.e., near to and west of the Panama Canal), we drove on accessible roads in the provinces of Colón and $\mathrm{Pa}$ nama both west and east of the Panama Canal, and the Pan-American Highway and side roads west to the city of Santiago de Veraguas, which is $100 \mathrm{~km}$ beyond the westernmost symptomatic palm we have observed. All palms clearly visible from the road were mapped using the GPS unit mounted on a car. This compressed the locations of palms to the nearest position on the road, with care taken not to count the same palm from multiple roads. In the road census, we mapped approximately 50,000 palms along approximately $750 \mathrm{~km}$ of roadway. Palms in central Panama are found in scattered patches, restricted primarily to small plantations and areas around homesteads and houses, so a road survey allowed us to inspect a large proportion of the palms in the region. These surveys were conducted annually from 1998 through 2006, with the exception of 2005.

Mapping local disease increase. To examine the local rate of spread of porroca, we monitored coconut palms located in small discrete plantations or on islands where disease was already established in 1998. In Nombre de Dios, we revisited 15 apparently healthy palms every 2 to 8 months between 14 January 1999 and 21 June 2001. In Kuna Yala, we followed the disease progress of individual coconut palms on three islands (Detail 3: $9.32081^{\circ} \mathrm{N}, 78.24050^{\circ} \mathrm{W}, n=233$ palms; Detail 4: $9.30667^{\circ} \mathrm{N}, 78.17994^{\circ} \mathrm{W}, n=49$; and Detail $7: 8.77244^{\circ} \mathrm{N}, 77.55756^{\circ} \mathrm{W}, n=$ 28) and three discrete mainland patches (Detail 1: $9.42847^{\circ} \mathrm{N}, 78.84350^{\circ} \mathrm{W}, n=18$; Detail 2: $9.35731^{\circ} \mathrm{N}, 78.35464^{\circ} \mathrm{W}, n=$ 153; and Detail 6: $8.78200^{\circ} \mathrm{N}$, $77.58036^{\circ} \mathrm{W}, n=230$ ) during the annual censuses from 1999 to 2001. All palms were mapped with sufficient detail to allow identification of individual palms from census to census. Each patch contained at least one symptomatic palm in 1999. In Nombre de Dios, porroca was already well established in nearby plantations, whereas in Kuna Yala, disease was rare in the landscape at the start of the study.

\section{RESULTS}

Symptomology. Porroca of coconut is characterized by extreme dwarfing of new leaves (Fig. 2A, C, and E), so that in the course of 2 to 3 years, a palm is left with only a tuft of very small leaves (Fig. 2B), followed soon by death of the palm. Symptomatic leaves are short with rigid leaflets of a normal green color, usually with some necrosis that gives them a "burnt tip" appearance. Onset of symptoms is abrupt, with a sharp transition to producing new 
leaves less than one-half the length of normal. Palms with the "classic" porroca silhouette demonstrate a typical abrupt transition from long, healthy leaves to dwarfed leaves (Fig. 2A and E). Only leaf length and form is affected, not the number of leaflets. Symptomatic leaves were less than one-half the length of healthy leaves (209 $\pm 37 \mathrm{~cm}, n=48$ versus $488 \mathrm{~cm} \pm 43$ cm, $n=56$, respectively) (Fig. 2C). The number of leaflets per leaf did not differ between healthy leaves $(104.6 \pm 4.8, n=5)$ and symptomatic leaves $(98.0 \pm 4.4$ leaflets per leaf, $n=3)(t=1.9, \mathrm{df}=6$, and $P=$
$0.10)$, but leaflet density (142.3 \pm 13.7 leaflets per meter) was more than sixfold greater on symptomatic leaves than on healthy leaves $(t=20.6$, df $=6$, and $P=$ 0.0001 ).

In the earliest known description from Colombia, Ferrand (5) noted gray longitudinal streaks at the base of the petioles of the apparently healthy basal leaves, with streaks increasing in intensity on symptomatic leaves. We found this to be variable, with discoloration found at the bases of fewer than one-half of the leaves on four dissected palms. Streaks were not associ- ated with mycelium, fungal reproductive structures, nematodes, or signs of any other pathogens (5). Internally, the apical meristem of symptomatic palms, including developing leaf and flower buds, were white, intact, and free from any signs of necrosis, rot, or damage.

The trunk diameter of symptomatic palms decreases sharply at the growing apex (Fig. 2B and F). This reduction is abrupt and rapid, over a distance of a few tens of centimeters. A tapering trunk diameter can be caused by many factors and is often observed in palms growing in un-
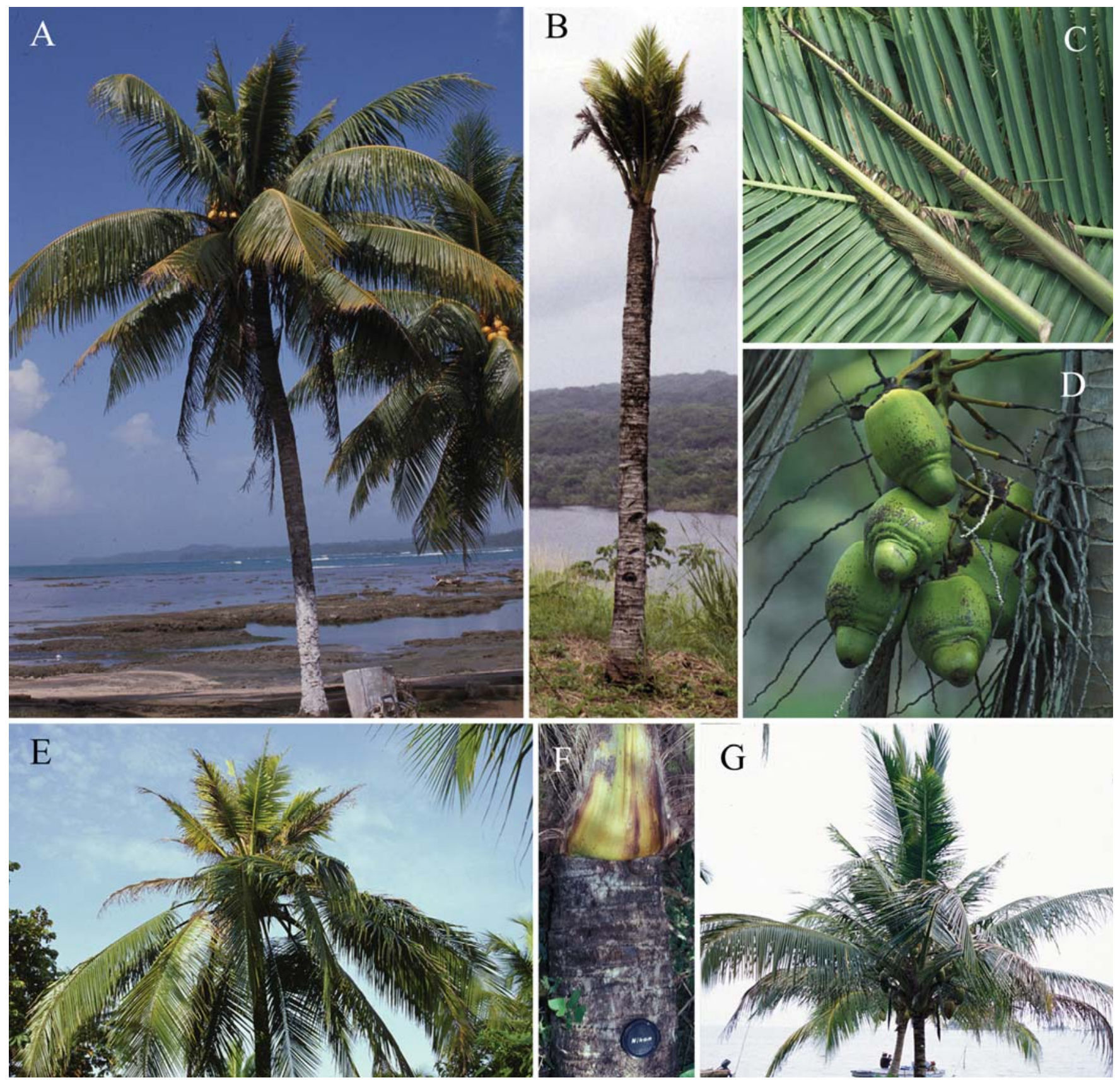

Fig. 2. Symptoms of porroca disease of coconut. A, Newly developed leaves are abruptly and extremely dwarfed compared with healthy basal leaves. Palms in this advanced state generally die within 2 years ( 24 leaves) of producing the first dwarfed leaf. B, As basal leaves naturally senesce over 2 to 3 years, the affected palm is left with only dwarfed leaves. C, Leaves of a severely affected palm (foreground) have short, dense leaflets compared with the leaf of a healthy palm (background). D, Fruits produced during the first few months of symptoms are small and deformed. E, The silhouette of a palm that had been symptomatic for more than a year. F, Trunk diameter at the apex reduces rapidly in affected palms. G, Occasionally, symptomatic palms recover, abruptly producing leaves of normal length. 
favorable soils or poorly managed plantations, but in those cases, the diameter reduction is more gradual, reducing over a meter or more. Symptomatic palms may continue to produce fruit for several months, but fruits are small and deformed (Fig. 2D); palms in advanced stages of porroca no longer produce fruit (Fig. 2B).

Although porroca is usually fatal, palms may sometimes recover with the symptoms disappearing as abruptly as they appear (9). A palm with classic symptoms-large, healthy, older leaves, symptomatic dwarfed, younger leaves, and strongly reduced apical trunk diameter-can abruptly produce leaves of normal length and the apical trunk diameter again increases (Fig. 2G).

Distribution and spread in Panama. Porroca spread rapidly in Panama between 1998 and 2006 (Figs. 3 and 4). In 1998, it was locally common but still restricted to mainland sites in eastern Kuna Yala (near Puerto Obaldia at the Colombian border) and in Colón Province east of the Panama Canal. A few symptomatic palms were found along the Transisthmian Highway between Colón and Panama City and in isolated clumps along the Pan-American Highway on the Pacific slope west of the canal.

By 2000, however, symptomatic palms had spread westward throughout the Comarca of Kuna Yala and appeared on 53 islands across the archipelago (Fig. 3). In addition, the incidence of porroca intensified greatly in Colón Province, along the Transisthmian Highway and westward along the Pan-American Highway (Fig. 4). Most new infections were of only one to several palms on an island or a mainland area, whereas areas with long-established infections contained many symptomatic palms. Overall, the number of symptomatic palms in Kuna Yala increased 18fold in 2 years, with 46, 627, and 827 symptomatic palms in 1998, 1999, and 2000, respectively, with new infections appearing as much as $40 \mathrm{~km}$ from previously known infections. Although the rate of increase is dramatic, these individuals represented only $0.6 \%$ of coconut palms in Kuna Yala. In 2001, however, we found only 570 symptomatic palms, and many previously symptomatic palms had died or recovered. Because of the coarse temporal scale of our surveys, it is difficult to calculate an accurate rate of recovery. However, if we divide the observed number of recovered palms by the number of palms with porroca symptoms in the previous year we estimate $21.4 \%$ recovery for $1999-2000$ and $21.5 \%$ recovery for 2000-2001.

Road surveys showed that porroca was established throughout Colón Province and immediately west of Panama City by 1999 . Disease incidence remained stable overall from 1999-2001 (1999; 691/34,876 (1.98\%): 2000; 622/29,770 (2.09\%): and 2001; 695/38,612 (1.80\%) (Fig. 4). However, in central Panama, among the 8,100 palms surveyed along the Pan-American Highway south of $8.8^{\circ} \mathrm{N}$ latitude, incidence of porroca increased 10-fold over 7 years (1999; 0.2\%: 2000; 0.48\%: 2001; $0.48 \%$ : and 2006: $2.52 \%$ ). The disease front of porroca spread at least $45 \mathrm{~km}$ southwest along the Pan-American Highway between 1999 and 2006 (Fig. 4). Two outlying palms with porroca symptoms seen in 2001 west of Penonomé were not found again in a visit in 2004 (census data not presented) nor in the 2006 census.

Local disease increase. Over 2 years, 7 of 15 originally healthy palms in one small plantation (Nombre de Dios) developed symptoms of porroca. In the six Detail areas selected for study of individual palms over time (Fig. 3), the local rate of increase of porroca was highly variable. Detail 7 showed a 1.8-fold increase in porroca incidence. In contrast, two sites showed as much as $50 \%$ decline in porroca incidence, in one case primarily because diseased palms died and in the other case because they recovered. The remaining three sites showed no change in disease incidence.

\section{DISCUSSION}

Porroca is a lethal disease of coconut that is currently spreading northward from Colombia into Central America. The spread of porroca can be rapid (we observed possible long-distance spread of as much as $40 \mathrm{~km}$ or more in some years) and its impact severe, but both of these characters can be temporally and spatially highly variable. At the leading edge of spread, symptomatic palms may simply die with no further local spread or disease incidence may increase very rapidly, quickly affecting as much as one-half of the palms in a discrete stand or on an island. Long-distance spread and local variability may mean that local measures such as culling will not be effective measures of disease control. A pilot experiment in Kuna Yala evaluating culling and traditional use of smoke as pest control measures on small, individual plantations did not yield measurable reductions in disease spread (unpublished data).

There is no evidence that porroca can be transmitted through seeds and such trans-

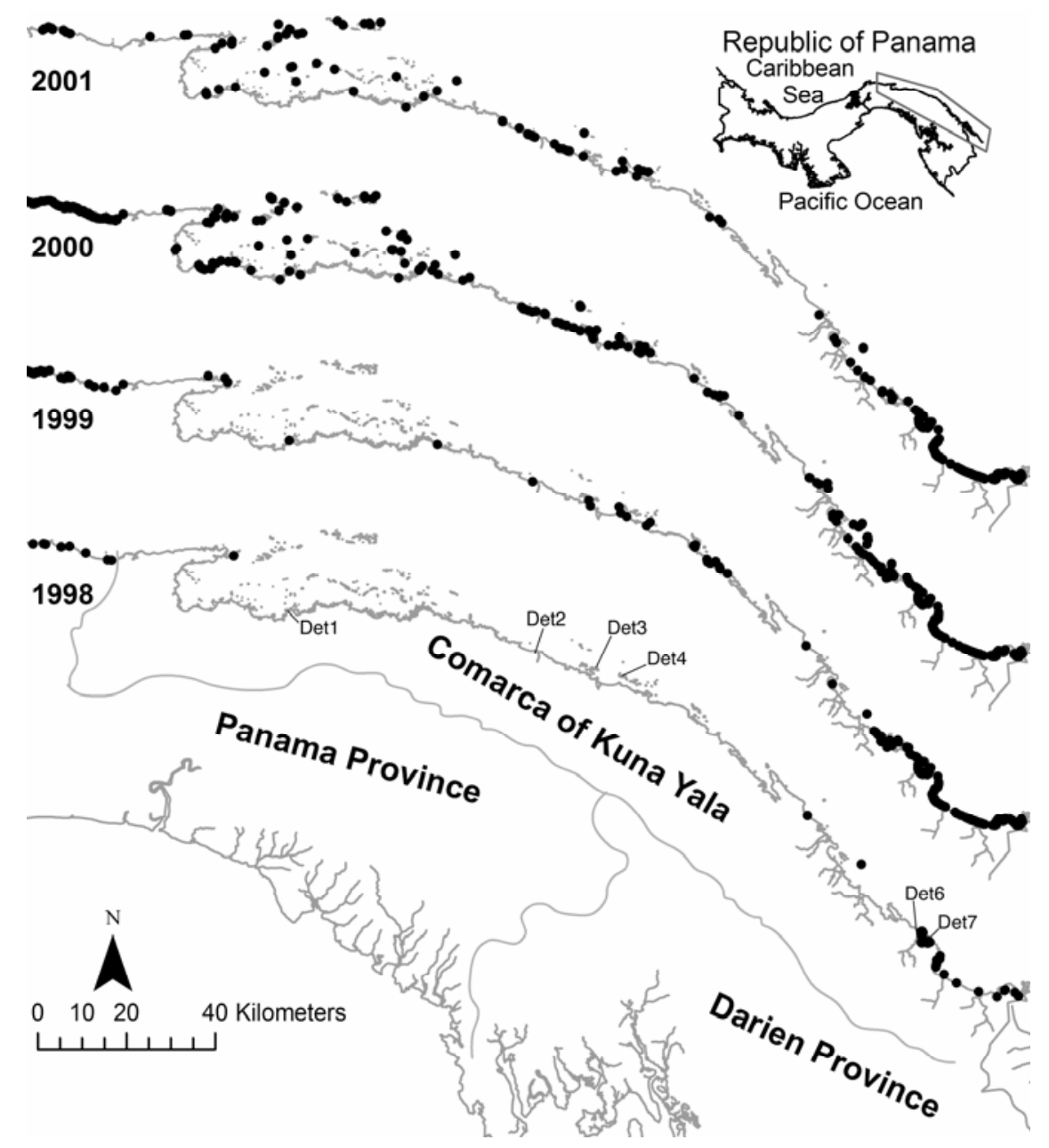

Fig. 3. Rapid spread of porroca through the Comarca of Kuna Yala, Republic of Panama, between 1998 and 2001. Filled circles in each year show the locations of symptomatic palms found during annual censuses of approximately 200,000 palms. No island or any stretch of coastline of more than a few hundred meters was without coconut palms. Outlines of Panama and Darien provinces are shown for geographic reference; surveys were conducted only along the Caribbean Coast and islands. Locations of six Detail sites for the temporal study of disease development on individually mapped coconut palms are indicated as Det1, Det2, Det3, Det4, Det6, and Det7. 


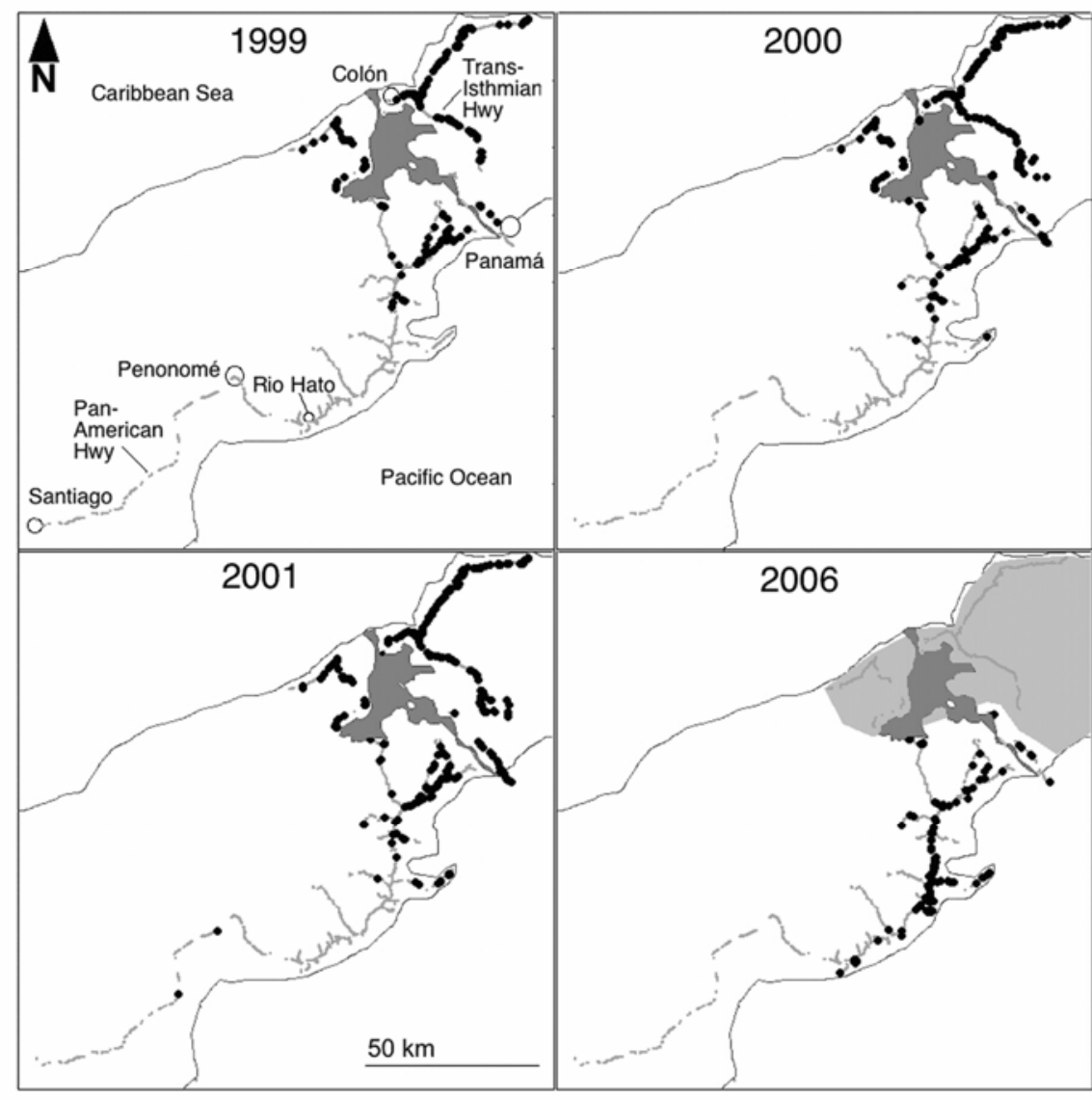

Fig. 4. Distribution and spread of porroca in central Panama. Small gray dots indicate positions of healthy coconut palms (and general path of the roads) and large black dots indicate palms with porroca symptoms. The gray area in the Colón Province was not surveyed in 2006.

mission is unlikely since fruit production ceases quickly with the onset of symptoms. Additionally, regional trade in fruits is almost exclusively with the Caribbean Coast of Colombia where porroca already exists, and thus seed transmission is unlikely to have large epidemiological consequences.

The phenomenon of recovery-the abrupt production of normal leaves after months of producing the dwarfed leaves typical of porroca-is intriguing and merits careful study. Recovery from symptoms is usually associated with virus, viroid, or phytoplasma infections $(1,2,7)$. We have detected a Stolbur-group (16SrXII) phytoplasma in meristematic tissue of palms with porroca symptoms (N. Harrison, G. Gilbert, and I. Parker, unpublished data), but have not been able to demonstrate yet that it is the cause of porroca.

It is not known whether porroca can affect other palms in agricultural or forest ecosystems, although we have not observed porroca-like symptoms in other species of palms during 9 years of work in porroca-infested areas. Elucidation of the causal pathogen will facilitate examination of host range, potential vector associations, and mechanistic studies of pathogen spread.

The threat to coconut production in Central America is potentially large if porroca continues its recent rate of spread. Compared with eastern and central Panama, coconut density in western Panama is low and patchy, even along the coasts where mangrove forests and low human popula- tions do not support extensive stands of coconuts. It is possible that this low density of coconuts may slow or prevent the continued westward movement toward Costa Rica and the rest of Central America, but the long-distance movement seen in Kuna Yala suggests otherwise.

\section{ACKNOWLEDGMENTS}

We thank Edgardo Soo, Victor Manuel Avila, Bennet Preston, Luis Muñoz, and Jose Meza for help in the field, and Brian Fulfrost for GIS guidance. The Ministerio de Desarollo Agropecuario and the Autoridad Nacional del Ambiente of the Republic of Panama, as well as Sr. G. Olmos, facilitated work in Panama and access to coconut plantation sites. We especially thank the Congreso General Kuna, IDIKY, and the Kuna People for permission to work in the Comarca of Kuna Yala and for logistical support, hospitality, and friendship. This work was supported by grants from the Berkeley Faculty Fund and the USCS Committee for Research and the generous support of the Jane Carver Foundation.

\section{LITERATURE CITED}

1. Baulcombe, D. 2004. RNA silencing in plants. Nature 431:356-363.

2. Carrillo-Tripp, J., Lozoya-Gloria, E., and Rivera-Bustamante, R. F. 2007. Symptom remission and specific resistance of pepper plants after infection by Pepper golden mosaic virus. Phytopathology 97:51-59.

3. Esquivel, E. A. 1997. Observaciones sobre la porroca o necrosis apical del cocotero, Cocos nucifera L. en Panamá. Page 174 in: XLIII Reunión PCCMCA, Resumenes, Panamá.

4. Esquivel, E. A. 1999. La Porroca o necrosis apical del cocotero. Ecos del Agro (Panamá) Agosto: 18 .

5. Ferrand, M. 1960. Colombia - Plantas oleaginosas y especialmente palma de aceite (Elaeis guineensis) - Informe al gobierno. Food and Agriculture Organization of United Nations.

6. Howe, J., and Chapin, M. 1975. Notes on the environment and subsustence practices of the San Blas Cuna.

7. Morone, C., Boveri, M., Giosue, S., Gotta, P., Rossi, V., Scapin, I., and Marzachi, C. 2007. Epidemiology of flaveseence doree in vineyards in northwestern Italy. Phytopathology 97:1422-1427.

8. Muñoz, L. 1994. La Porroca de cocotero en Panamá. Page 9. Ministerio de Desarrollo Agropecuario (MIDA), Colón, Republic of Panamá.

9. Ramirez Naranjo, B. 1991. Principales enfermedades del cocotero. ICA Informa Colombia 25 (Oct-Dec):5-13.

10. Stier, F. 1982. Domestic economy: Land, labor, and wealth in a San Blas Community. Am. Ethnologist 9:519-537.

11. Tice, K. E. 1995. Kuna Crafts, Gender, and the Global Economy. University of Texas Press, Austin, Texas. 